\title{
What About the IPA(Invertebrate Primitive Antibody) Schema
}

\author{
Michel Leclerc \\ 556 rue Isabelle Romée, 45640 SANDILLON (FRANCE) \\ *Corresponding Author: Michel Leclerc, 556 rue Isabelle Romée, 45640 SANDILLON (FRANCE).
}

\section{ABSTRACT}

The schema of sea star Asterias rubens IPA is purposed in this communication, since we discovered it (in 1986): it was isolated and analysed.

\section{INTRODUCTION}

In 2014, it was asserted by the discovery of IPA gene which matches to human Igkappa gene.

In 1986, we discovered ( Ref.1) the sea star antibody-like; it was isolated and analysed by the mean of biochemistry.

Its molecular weight was of 120.000 daltons and was composed of 4 sub-units of 30.000 daltons each, without disulfide bonds. 30 years later ( Ref.2) we found an IGKAPPA gene in the sea star (Asterias rubens), the antibody-like became the IPA (Invertebrate Primitive Antibody). We suggested it was made of 4 KAPPA Light chains. Always later we discovered in the sea star genome ( Ref.3) a Fab gene, a $\mathrm{Fc}$ receptor gene, a $\mathrm{Cr}$ receptor gene ( Ref.3), at last MHC genes which match to Human genes.

We try to imagine the IPA in the following schema (Fig.1)

This schema, in conclusion, at the same time, causes a feeling of pride and anguish, in front of my responsibility as a scientist.

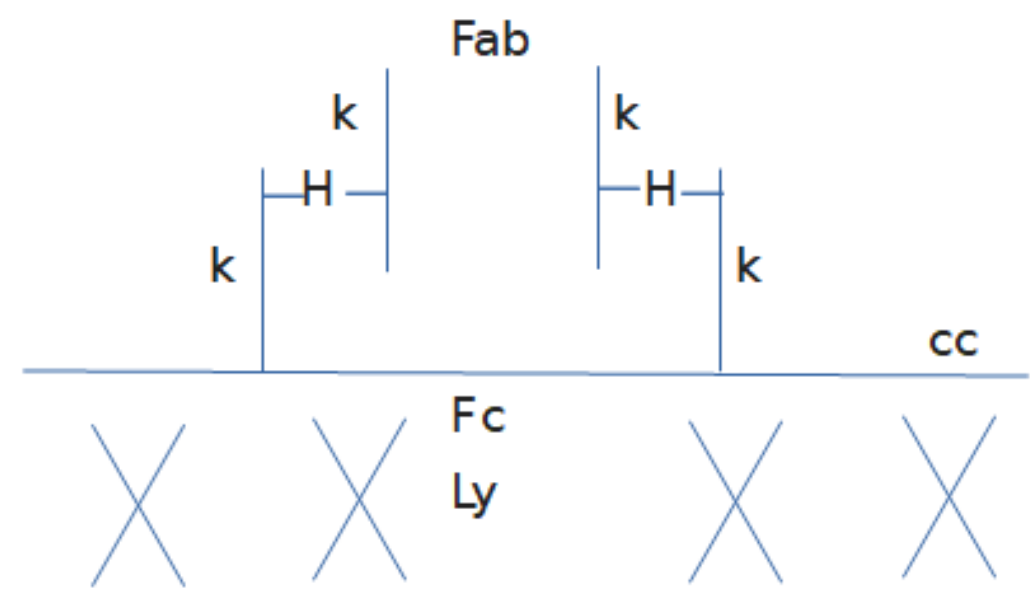

Figure1. IPA Schema

K: kappa chain; Ly: sea star Lymphocyte; cc: cell coat; H:Hydogen bond; Fab (fragment); Fc receptor

\section{REFERENCES}

[1] Delmotte F. Et al (1986) Eur.J.Immunol 111325-30

[2] Vincent N. Et al (2014) Meta Gene 2 320-322

[3] Leclerc M. (2018) MOJ Immunology 6(6) 326-27

Citation: Michel Leclerc, "What about the IPA (Invertebrate Primitive Antibody) Schema”, International Journal of Research Studies in Medical and Health Sciences. 2020; 5(1): 19-19.

Copyright: () 2020 Michel Leclerc, This is an open-access article distributed under the terms of the Creative Commons Attribution License, which permits unrestricted use, distribution, and reproduction in any medium, provided the original author and source are credited. 